\title{
Health Risk Assessment on Heavy Metals Ingestion through Groundwater Drinking Pathway for Residents in an Oil and Gas Producing Area of Rivers State, Nigeria
}

\author{
Raimi Morufu Olalekan', Adedoyin 0. Omidiji2, Deinkuro Nimisngha ${ }^{3}$, \\ Oluwaseun E. Odipe ${ }^{4}$, Awogbami Stephen Olalekan ${ }^{5}$
}

\begin{abstract}
${ }^{1}$ Department of Community Medicine, Environmental Health Unit, Faculty of Clinical Sciences, Niger Delta University, Wilberforce Island, Nigeria

${ }^{2}$ Department of Geography and Environmental Management, Faculty of Social Sciences, Niger Delta University, Wilberforce Island, Nigeria

${ }^{3}$ Department of Civil and Environmental Engineering, University of Strathclyde, Glasgow, UK

${ }^{4}$ Department of Environmental Health Sciences, School of Allied Health and Environmental Sciences, College of Pure and Applied Sciences, Kwara State University, Malete, Nigeria

${ }^{5}$ Department of Environmental Health Science, Ekiti State College of Health Sciences and Technology, Ijero-Ekiti, Nigeria Email:ola07038053786@gmail.com,morufu.raimi@waldenu.edu,doyinomidiji@yahoo.com, chat2nimi@gmail.com,

odipe@yahoo.com, lekan_steve@yahoo.com
\end{abstract}

How to cite this paper: Olalekan, R.M., Omidiji, A.O., Nimisngha, D., Odipe, O.E. and Olalekan, A.S. (2018) Health Risk Assessment on Heavy Metals Ingestion through Groundwater Drinking Pathway for Residents in an Oil and Gas Producing Area of Rivers State, Nigeria. Open Journal of Yangtze Gas and Oil, 3, 191-206. https://doi.org/10.4236/ojogas.2018.33017

Received: November 8, 2017

Accepted: July 14, 2018

Published: July 17, 2018

Copyright $(2018$ by authors and Scientific Research Publishing Inc. This work is licensed under the Creative Commons Attribution International License (CC BY 4.0).

http://creativecommons.org/licenses/by/4.0/ cc) Open Access

\section{Abstract}

In the study, health risk assessment on heavy metals ingestion was presented through the groundwater drinking pathway for residents in an oil and gas producing area of Rivers State, Nigeria. The level of the ground water pollution was examined, the quality of the borehole and the well water was assessed and the quality of the ground water pathway for the resident in the oil and gas producing area was determined and compared with the national and international standards for the drinking water. This study adopted both the field and laboratory experimental analysis of physical and chemical parameters. Water samples were analyzed for Physico-chemical parameters following acceptable methods to determine the compliance, and the results were analyzed according to drinking water guidelines. Interestingly, the results show that the ground water contained high amounts of turbidity (21.5 NTU, 23.00 NTU and 19.0 NTU in the borehole water and well water), iron $(5.3 \mathrm{mg} / \mathrm{L}$ in the ground water and $6.98 \mathrm{mg} / \mathrm{L}$ in the borehole water) and $\mathrm{pHs}$ of all water samples were acidic in the study area. These results show that ground waters including the borehole and the well waters of the study area had acquired reasonable levels of pollution. Whereas, other values were found to be lower or above and cor- 
responding to the acceptable threshold limit values for the drinking water set by consensus standards. A high value of turbidity due to suspended minerals is the cause for milky-white colour. Hence, ground waters in the study area are mainly unsuitable for drinking (containing iron, $\mathrm{pH}$ and turbidity). This study clearly advises that some health deteriorating chemicals in the drinking water were at dangerous level and; therefore, the water quality could be a major health menace for residents of the oil and gas producing area of Rivers state. Furthermore, additional researches in medical test to ascertain the health of the people are recommended in this study. Comprehensive groundwater monitoring and adequate treatment should be implemented. The government should carry out clean-up exercise immediately because there is oil spill to prevent infiltration of oil into the groundwater. There is also a need for the continuous monitoring and auditing of water quality in the oil producing areas so as to protect the men and the environment.

\section{Keywords}

Health Risk, Heavy Metals, Oil Spill, Ingestion, Groundwater, Rivers State, Nigeria

\section{Introduction}

Some of the recent water quality studies include: an assessment of trace elements in surface and ground water quality in the Ebocha-Obrikom oil and gas producing area of Rivers State, Nigeria by Raimi and Sabinus (2017) [1]; Morufu and Clinton, (2017) [2], water-related problems and health conditions in the oil producing communities in central senatorial district of Bayelsa State by Raimi et al. (2017) [3], water quality on intermittent water supply by Erickson et al. (2017) [4], major ion chemistry of the groundwater by Bikundia and Mohan (2014) [5], water quality due to temperature variation and water stagnation by Zlatanoviæ et al. (2017) [6], the use of fluorescence spectroscopy for tap water quality assessment by Heibati et al. (2017) [7], Hydrochemical evolution and quality of groundwater by Jassas and Merkel (2015) [8], and evaluation of hydrogeology and groundwater quality by Edet (2016) [9]. Water quality was also studied in different areas of the world by Dhamodharan et al. (2016) [10], Li et al. (2016) [11], Nagaraju et al. (2016) [12], Kumar et al. (2017) [13], and Tiwari et al. (2017) [14].

In most parts of the Niger Delta region of Nigeria, the major challenge of survival is the provision of good quality (potable) water because of environmental pollution and degradation [15]. In most cities, towns and villages in this region, valuable man-hours are spent on seeking and fetching water of doubtful quality to meet specialized needs [16] [17].

\section{Objectives of the Study}

This study examined the health risk assessment on heavy metals ingestion 
through groundwater drinking pathway meant for human consumption in the Ebocha-Obrikom oil producing area of River State, Nigeria.

To achieve this, the following specific objectives were to:

1) Examine the level of ground water pollution in the study area

2) Determine the quality of ground water in the study area and compared with national and international standards for drinking water.

3) Assess the quality of borehole and well water in the study area.

\section{Materials and Methods}

\subsection{Study Area}

The Ebocha-Obrikom area is located between latitude $5^{\circ} 20^{\prime} \mathrm{N}-5^{\circ} 27^{\prime} \mathrm{N}$ and longitude $6^{\circ} 40^{\prime} \mathrm{E}-6^{\circ} 46^{\prime} \mathrm{E}$ (Figure 1). It comprises Obrikom, Obor, Obie, Ebocha and Agip New Base towns all in Ogba/Egbema/Ndoni Area of Rivers State (Figure 1). The study Area is bounded to the North by Nkissa River, by the West, the Orashi River, by the East, the Sombrero River and by the South Omoku town.
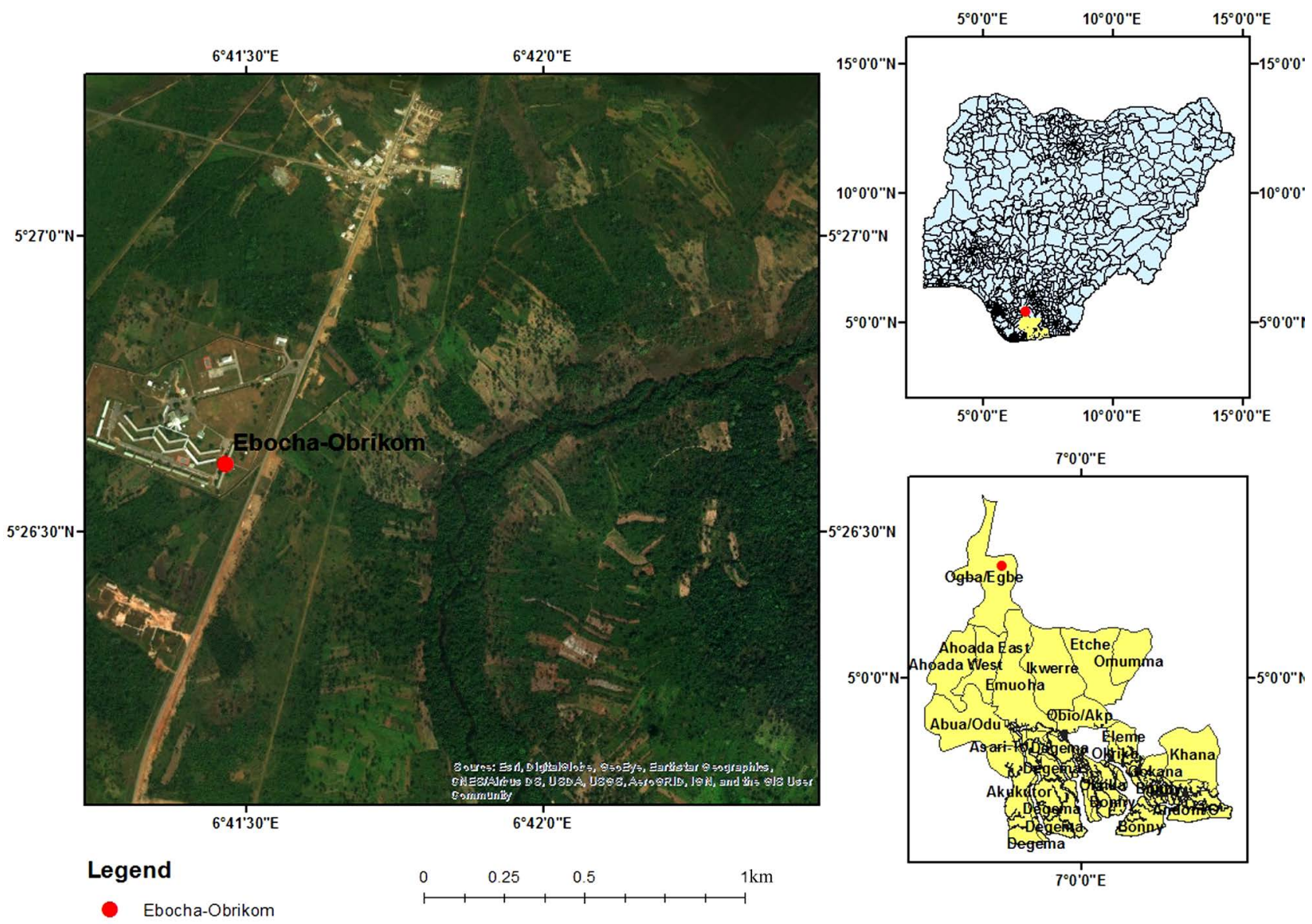

Figure 1. Map Showing the Study Area with Nigeria and River State insert.

\subsection{Sample Collection}

Sample collections were limited to the groundwater. Ground water sources were 
randomly selected within the vicinity of the depot, but at different distances from each other. The samples were also collected manually into clean plastic sampling bottles from eight strategic locations in the study area for ground water (boreholes and wells).

The locations include: Ebocha (Green River), New Base (NAOC), Obrikom (Abacha Road), Obor (Eagle Base), Obie (Obor Road), Agip Gas Flaring Centre, Apple Hotel, Egbeda (Agip Flaring Stack).

All the samples were taken in the daytime between 9.00 am and $3.00 \mathrm{pm}$. Night samples were not collected because of insecurity. The sampling was carried out between October 2015 and December 2015.

\subsection{Sampling, Preservation and Analysis}

The water sampling and the analysis follows standard procedures described in APHA [18].

\section{Results and Discussion}

\subsection{Results}

\section{Analysis of Variation of Physico-Chemical Parameters at Different Locations}

Table 1 shows the results of the analysis of variance of the variables tested. There is an insignificant difference in ORP, TDS, pH, Conductivity, Turbidity, Salinity, Temperature, Altitude, Well depth, COD, BOD, Iron, Manganese and Zinc between the five locations under the study $(p>0.05)$. But as for the dissolved oxygen $(p=0.000), \mathrm{SO}_{4}(p=0.014)$, total alkalinity $(p=0.030)$, total harness $(p=$ $0.034)$ significant differences result were obtained $(p<0.05)$. The result also reveals that dissolve oxygen in New base, Obrikom, Obor and Ebocha was significantly higher than that of Egbeda while that of Newbase, Obrikom and Obor were significantly higher than that of Ebocha $(p<0.05)$. The level of $\mathrm{SO}_{4}$ in Newbase was found to be significantly higher than that of other locations $(p<$ 0.05) while between Ebocha, Obrikom, Obor and Egbeda, no significant result was obtained $(p>0.05)$. For total hardness, it was significantly higher in Egbeda than that of the remaining four locations $(p<0.05)$. Also, for Iron, it was significantly higher in Obor than that of the remaining four locations.

Table 2 shows the result of the assessment of the quality of ground water in the study area. The result shows that for the ground water, out of the 22 physico-chemical parameters only analyzing dissolved oxygen, the temperature, the biological oxygen demand and total petroleum hydrocarbon (TPH) are within the WHO standards. The result obtained for other physico-chemical parameters are outside the recommended WHO standards. Similarly, for groundwater, only the temperature and the lead are within the NAFDAC recommended standards. Other parameters are outside the standards.

Table 3 shows the quality of borehole and the well water in the study. Result shows that of the 22 physico-chemical parameters analyzing the borehole water, dissolved oxygen (DO), the temperature, the biological oxygen demand 


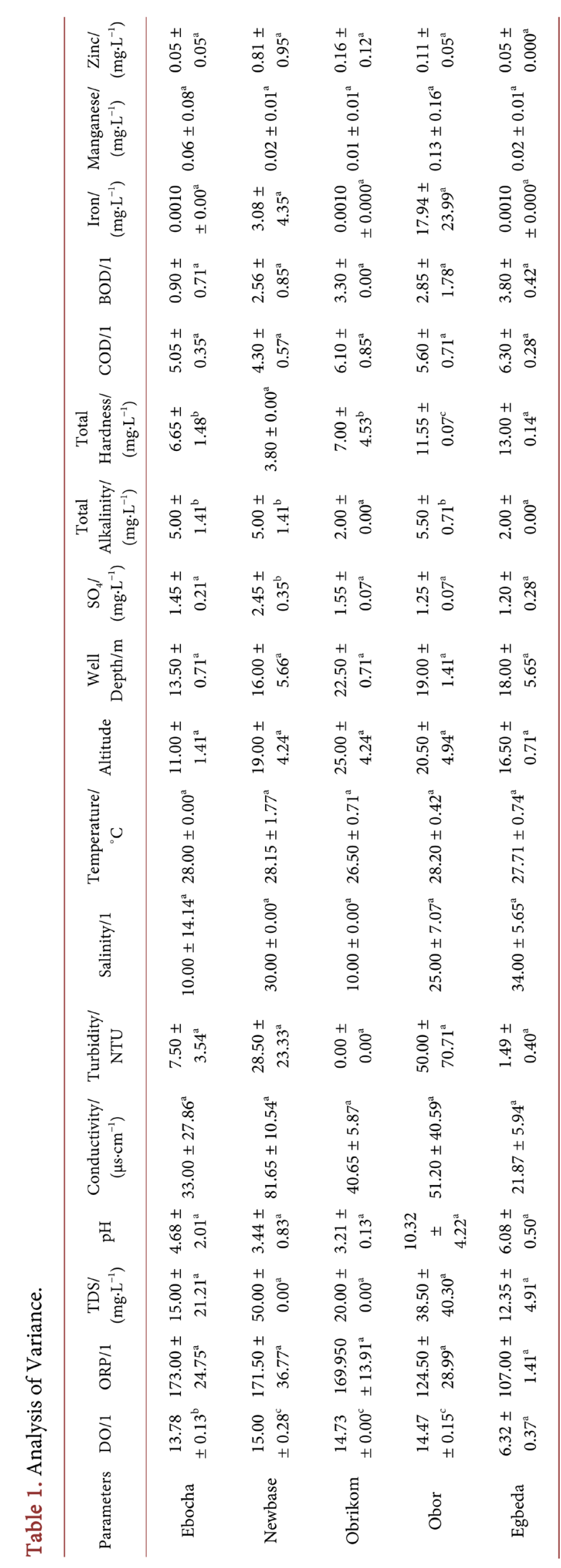




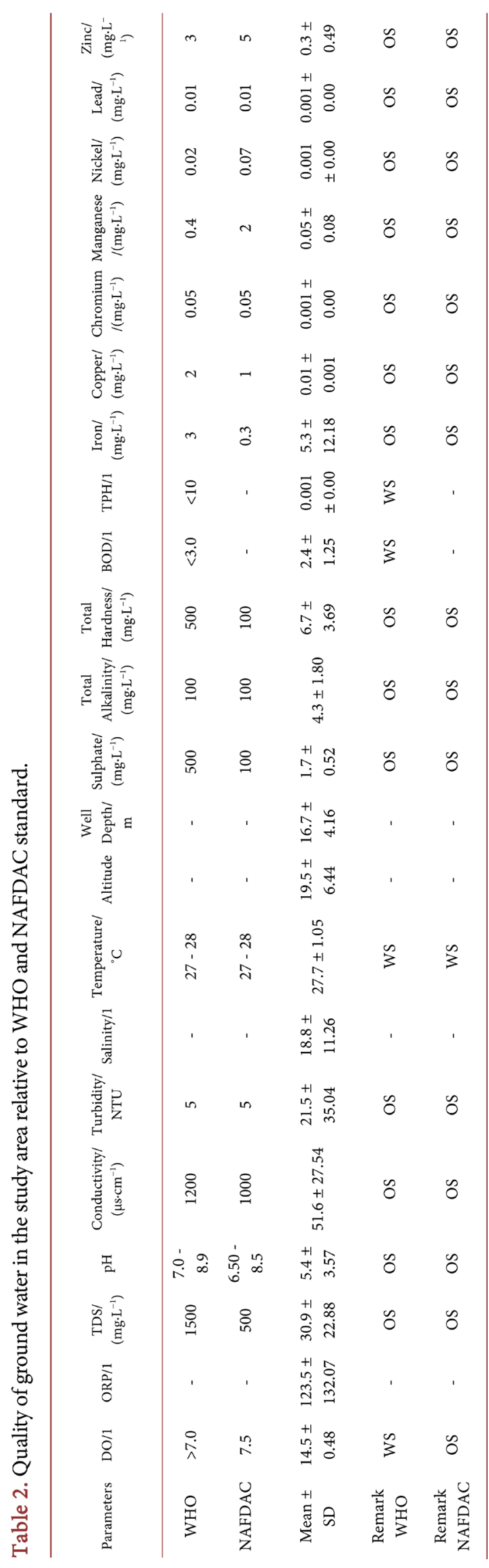




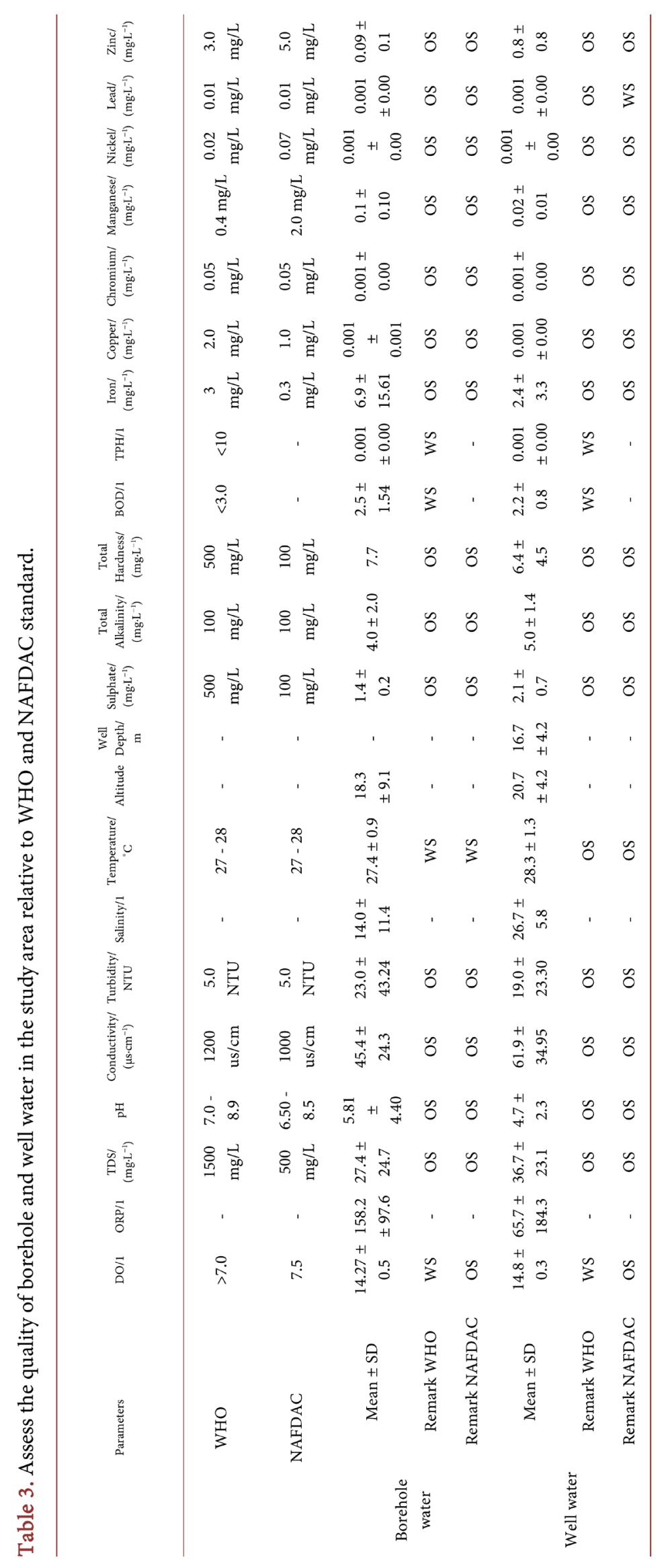


(BOD) and total petroleum hydrocarbon (TPH) are within World Health Organisation standard. Other parameters are outside the standard values as recommended by WHO. For Well water, only dissolved oxygen (DO), biological oxygen demand (BOD) and total petroleum hydrocarbon (TPH) are within the standard. Other parameters are outside the standard value. Similarly, for the borehole water, only the temperature is found to be within NAFDAC standard while for well water, only the lead is found to be within the NAFDAC standard. Also, the temperature was a little bit above the standard ranges of $27^{\circ} \mathrm{C}-28^{\circ} \mathrm{C}$. The result obtained for other physico-chemical parameters are outside recommended standards.

\subsection{Discussion}

\subsubsection{Variation of Physico-Chemical Parameters at Different Locations}

The result reveals that the dissolved oxygens in New base, Obrikom, Obor and Ebocha are significantly higher than that of Egbeda while that of Newbase, Obrikom and Obor are significantly higher than that of Ebocha $(p<0.05)$. Thus, it could be deduced that higher rate of anthropogenic activities is present in Ebocha, New base, Obrikom and Obor and seem to influence dissolved oxygen more than in Egbeda. The level of $\mathrm{SO}_{4}$ concentration in the ground water in Newbase is found to be significantly higher than that of other locations $(p<0.05)$ while between Ebocha, Obrikom, Obor and Egbeda no significant result is obtained ( $p>$ $0.05)$. The very high values of sulphate in ground water at Newbase could be attributed to the agricultural contamination from fertilizers which latter seeped underground to mix with ground water. Also, it could be stated that sulphate is very unstable in the atmosphere from where they are converted into forms suitable for their stay in ground waters [2] [19]. Total alkalinity was the highest at Ebocha, Newbase and Obor respectively. The high rate alkalinity could be attributed to the continuous release of acidic substances into its adjoining environments which later percolate the underground [2] [19], hence the contrasting relationship between the three locations. For total hardness, it was significantly higher in Egbeda than the remaining four locations $(p<0.05)$.

\subsubsection{Quality of Groundwater, Borehole and Well Water}

The analysis of dissolved oxygen (DO) is used to measure the amount of gaseous oxygen dissolved in the water, which is crucial for all forms of life, as oxygen $\left(\mathrm{O}_{2}\right)$ plays an influential role in nearly all chemicals and biological processes within water bodies [20]. The highest mean value of DO was recorded in borehole water and well water which were above the permissible criteria of National regulatory bodies. DO in liquid provides a source of oxygen needed for the oxidation of organic matter when the concentration is high and lack of it causes the water body to become dead or devoid of aquatic life [21]. This result shows that the support was found in Morufu and Clinton, (2017) [2] and Raimi and Sabinus (2017) [1] indicating that ground waters could also be conveniently used to support fish pond activities since DO values were above the recommended value 
of greater than 7 as stream standard for fishing [2]. Typically, DO levels less than $2 \mathrm{mg} / \mathrm{l}$ will kill fish [23]. Chapman and Kimstach (1992) [20] noted that DO concentrations below $5 \mathrm{mg} / \mathrm{l}$ adversely affect the functioning and survival of biological communities and below $2 \mathrm{mg} / \mathrm{l}$ may lead to the death of most lives. Oxygen is soluble in water and it tends to be less as the temperature increases.

The $\mathrm{pH}$ revealed that the maximum and minimum $\mathrm{pH}$ values in the water resources from all the sampling sites fall below the permissible criteria of National and International regulatory bodies. Therefore, it has made these sources of water available to the inhabitants of the area as low-quality water [1]. The collected $\mathrm{pH}$ values of the samples are found to be relatively low; and the recorded low $\mathrm{pH}$ values suggest the acidic precipitation within the immediate vicinity of the natural gas processing installation [23]. Optimum $\mathrm{pH}$ range for sustainable life is 6.5 - 8.2 [24]. Water that is too acidic or too alkaline can be detrimental to human health and lead to nutritional disequilibrium, which is demonstrated in an oil spilled area where both $\mathrm{pH}$ extremes are found to be problematic [25]. Acidic precipitation is known to pose a threat to various economic resources; fisheries, forestry, agriculture and wildlife [26]. Acidified waters may leach toxic metals from watersheds and water distribution systems, and the presence of these metals in drinking water can result in a number of serious human health impacts [23]. The observed acidic $\mathrm{pH}$ in this study agrees with the report of Abowei (2010) [27] that waters with little change in $\mathrm{pH}$ are generally more conductive to aquatic life. Furthermore, the recorded low $\mathrm{pH}$ values in the study also accord with the observation of Beadle (1981) [28] that rivers flowing through forests contain humid acid which is the result of decomposition and oxidation of organic matter and hence low pH. According to Aguwamba (2000) [29], the acidity of natural water is attributed to the presence of carbon-dioxide or strong mineral acids.

Borehole water also revealed some level of turbidity with the highest value of 23.00 NTU. However, the turbidity values are above the maximum permissible limit of 5 NTU for drinking water [30] [31]. Conversely, the medium range of turbidity consequent on oil related activities like gas flaring and oil spillage could have serious health implications for the residents within the studied areas [1] [2] [22]. This may be related to the presence of particles of clay, silt, organic component and other microscopic substances. It may also be an indication of deposite of pollutant loads in Ebocha-Obrikom and its environs. This result corroborates earlier reports by Udoessien (2003) [32] that turbidity helps to indicate the degree of harmfulness of the water. This also accords with the findings of Longe and Enekwechi (2007) [33]; and Morufu and Clinton, (2017) [2] who concluded that it is attributed to the leaching from the oil activities and pipeline vandalisation in the study area.

Iron occurs in high concentration in groundwater and borehole water compared to well water which were generally below the maximum tolerable limit of National and International regulatory bodies. This suggests some dissolution of iron $(\mathrm{Fe})$ within the soil particles. It could be due to gas flaring effects. The levels 
of iron in the borehole waters compare significantly with the reported levels in Niger Delta [34]. High concentration of iron (Fe) in the Niger Delta has also been reported by Emoyan et al, (2009) [35] and Akporido (2000) [36]. The presence of high concentration of iron $(\mathrm{Fe})$ recorded impacted colour and also developed turbidity. This is an indication of pollution at borehole water and ground water. The results of this study agree with earlier report by Morufu and Clinton, (2017) [2] that iron concentration in groundwater is closely related to that of borehole water. The high rate of iron in groundwater can also be due to high rate of evaporation which left less volume of water in the borehole, hence the concentration of iron. Also, it may be attributed to the degree of ferruganization of the aquifer materials, quality of ground/borehole water materials and improper construction of the borehole. The borehole materials could be of poor quality and as a result become prone to rusting while the improper construction of the borehole will allow extraneous fluids like oxygen to feed the well [37].

The report of Egila et al. (2001) [38] on oxygen converts the soluble ferrous ion to insoluble ferric ion. It is added that this will further degrade the quality of water in terms of the iron content. In addition, Edet and Ntekim (1996) [39] stressed that the geologic materials around the borehole sites may contain a lot of peat, lignite and organic mud bed that are pyritic. He stated that iron can be leached out of pyrite and entrained in the groundwater system and if the quantity is high, it will contaminate the groundwater systems. Also, Moriber (1994) [40] some heavy metals are naturally present in some natural water sources. This possibly explained the levels of iron contents in the samples. The few excessive concentrations of iron obtained in this work may be injurious to health because iron is a potent dietary antagonist of copper metabolism in ruminant [41]. Iron however, is an important element required for the synthesis of haemoglobin during haemopoiesis in the bone marrow [24]. Iron also promotes the growth of iron bacteria, often taste unpalatable and strains laundry and plumbing features as a result of the precipitation of $\mathrm{Fe}(\mathrm{OH})_{3}$ from unstable $\mathrm{FeSO}_{4}$ present in water [42]. The results also corroborate the findings of Morufu and Clinton, (2017) [2], Waziri, (2006) [43], and Raimi and Sabinus (2017) [1] that although, iron in drinking water is not a major health concern, concentrations above $3 \mathrm{mg} / \mathrm{l} \mathrm{can}$ cause food and water to become discoloured and taste metallic. Iron deficiency in the human blood could lead to anemia while excess of it could generate free radicals into the system which could speed up the aging process [19].

Results of the analysis reveal the low concentration of trace metals $(\mathrm{Cu}, \mathrm{Cr}$, $\mathrm{Mg}, \mathrm{Ni}, \mathrm{Pb}$ and $\mathrm{Zn}$ ) in majority of the sample recorded in the study area. Trace amounts of metals are common in water, and these are normally not harmful to our health. Cobalt, Copper, Iron, Manganese and Zinc etc. are needed at low concentrations as catalysis for enzyme activities. [23] Drinking water containing high levels of either essential metals or toxic metals may be hazardous to our health [23]. The mean concentrations of the heavy metals in the analysed water samples are all found to fall below permissible criteria of National and International regulatory bodies. This suggests a good heavy metal abatement installation 
at the crude oil processing plants by the Agip oil company present in the study area. Well water shows no presence of copper, and it was generally free from copper as contaminant. Copper could be a natural resource owing to its low concentrations as shown in this study [1] [19]. Copper is an essential substance to human life, but chronic exposure to contaminant drinking water with copper can result in the development of anemia, liver and kidney damage [2] [19] [22]. This disease is a result of drinking the water contaminated from the corrosion of water pipes made of copper and industrial wastes.

The highest value for Long term exposure to the lead as in over dependence on water sources could lead to the decreased performance in some tests that measure functions of the nervous system, weakness in fingers and wrists, emergence of wrinkles, small increases in blood pressure and anaemia while the exposure to high levels of lead could instantaneously lead to severe damages to the brain and kidneys, miscarriage as well as outright death [1] [2] [19] [44].

Zinc was observed at well water. The maximum permissible limit of $5 \mathrm{mg} / \mathrm{l}$ for zinc is not exceeded by any of the values. Zinc at these limits does not pose serious health and environmental effects [1] [2] [19]. The concentration of Zinc measured may seem insignificant, cumulative effect might be harmful to health. Ejelonu et al, (2011) [23] and Dami et al. (2012) [22] observed in their studies a strong relationship between contaminated drinking water with heavy metals and chronic diseases such as renal failure, liver cirrhosis and anemia and hair loss has been identified. Renal failure is related to $\mathrm{Pb}$ and $\mathrm{Cd}$ contamination. Liver cirrhosis is related to $\mathrm{Cu}$ and Mo where contamination of drinking water with $\mathrm{Ni} / \mathrm{Cr}$ and $\mathrm{Cu} / \mathrm{Cd}$ lead to hair loss and chronic anemia, respectively. In addition, chronic health effects include cancer, birth defects, organ damage, disorders of nervous system and damage to immune system [45]. Cd, Cu, Co, Cr, Mn, Ni, Pb and $\mathrm{Zn}$ are toxigenic and carcinogenic agents consistently found as contaminants in human drinking water supplies in many areas around the world [46]. The level of Zinc in the borehole and well water compared significantly with the reported level of the Niger Delta [2] [34].

According to Udo (2004) [41] zinc has been implicated in rickets-like diseases. It must also be noted that heavy metals, toxic or non-toxic are non-degradable and are therefore persistence in the ecosystem [41]. It is observed that to a large extent, most of the inhabitants of the rural communities depend on water from open wells for drinking, food processing or washing of utensils. It is therefore obvious that open wells play a major role in the provision of water for the rural dwellers; especially in communities where other sources of water like streams are located far from settlements. Also, given their dependence on well water, it is likely that people using such water would get infected with water borne diseases, if the well water is contaminated. According to Eja (2002) [47], persons infected with water borne diseases acquire infections through oral contact with contaminated water. This is also in consonance with the work of Raimi et al., (2017) [3] and Emoyan et al. (2005) [48] who reported that water borne diseases are those obtained by ingesting pathogens through drinking water or water that gets to the 
mouth from washing utensils and hands or through water used in the preparation of food. He added that such type of water arises from open wells that are polluted.

\section{Conclusions}

The drinking water quality is evaluated for residents in an oil and gas producing area of Rivers State, Nigeria in terms of the physico-chemical compositions of the ground waters, which have been shown to be above compliance standard for drinking in terms of iron $\left(\mathrm{F}^{-}\right)$, turbidity and $\mathrm{pH}$, respectively; high iron concentration and high $\mathrm{pH}$ value make ground water unfit for drinking. The ground water sources are slightly acidic and may have the tendency to cause health problems to the users. This may be attributed to emissions from gas flaring and petroleum refining activities, which is common in the area. Thus, the water quality of Ebocha-Obrikom communities is believed to be gradually deteriorating particularly in the study area. Therefore, by its present quality status it can be assumed that it is detrimental to human life. Results revealed that water quality status of Ebocha-Obrikom is adversely impaired with the discharge of industrial effluents, which dissolved and produce toxic substance at lower $\mathrm{pH}$ values.

Turbidity in the water was observed to be high and its aesthetic value seemed lowered because of wastes input from industries. Also, value of turbidity is high due to high dissolved mineral which was the cause for the milky-white colour of the water which can affect its acceptability for drinking.

Additionally, according to the Standards, objectionable levels of Iron concentrations are noted in all the groundwater sources. Likewise, the higher levels of Iron may expose the consumer of such water to health risks over time. Also, alarming are the consequences or chronic impacts of the levels of iron recorded in this aquatic ecosystem that may damage tissues because of iron accumulation and may result in development of a benign pneumoconiosis. Iron may cause conjunctivitis, chorditis and retinitis when contacted remained in the tissues. The presence of Iron in drinking water supplies is objectionable for several reasons unrelated to health. For example, water containing iron has taste and stains laundry and plumbing fittings and endorses iron bacterial growth. Furthermore, in the maximum protection of the health of the natives from the potential effects of exposure to Iron through ingestion of the contaminated ground waters and aquatic organisms, the ambient water concentrations of Fe in drinking water are normally $0.3 \mathrm{mg} / \mathrm{L}$ and the excessive limit is $1.0 \mathrm{mg} / \mathrm{L}$. Iron level gets much higher if the Iron gets corroded. This is very common with waste water or effluent from factories which are usually discharged into nearby water bodies using Iron pipes. The results suggest the use of such waters for drinking and domestic purposes may pose a threat to the health of the users and calls for the intervention of government agencies.

However, results of the study show that groundwater of the study area is contaminated with oil spillage. The effects on the indigenes may depend on the extent of consumption and their previous health history. If the treatment is not 
considered as soon as possible, there is no doubt that these health problems may cause low life expectancy and affect the productivity of the study area. Therefore, the importance of access to good quality water in this global era cannot be overemphasized to ascertain good health for the local residence.

\section{Recommendations}

This study therefore recommends that detailed medical tests should be carried out in further research to ascertain the health of the people, and adequate sources of drinking water should be provided to those households whose drinking water supplies are being impacted upon. Moreover, in view of the higher levels of iron recorded in the groundwater sources, it is recommended that one form of treatment or other may be required to reduce the risks associated with the consumption of high levels of iron. This may be achieved by exposing the contaminated water for about an hour followed by filtration since reverse Osmosis method for the treatment of iron may be too expensive for individuals, chambers containing lime be constructed and connected to the bores to increase the $\mathrm{pH}$ before consumption. Similarly, community water and sanitation agency and other philanthropists should make provision of good ground water quality a top priority and not just making water available. This may be achieved through thorough comprehensive groundwater monitoring and adequate treatment should be implemented in area earmarked for the provision of boreholes or wells, government should carry out clean-up exercise immediately there is spillage to prevent infiltration of oil into the groundwater. Furthermore, oil spill prevention, containment and counter measures should be put in place, signs should be posted around all sits identified as contaminated, warning the community not to engage in any activities close to polluted sites, campaign to end oil bunkering activity should be a joint initiative between the oil company, state and the local government authorities. Above all, the oil companies should therefore make concerted efforts to address this issue by carrying out proper clean-up and remediation methods to check-mate the problems.

\section{References}

[1] Olalekan, R.M. and Sabinus, C.E. (2017) An Assessment of Trace Elements in Surface and Ground Water Quality in the Ebocha-Obrikom Oil and Gas Producing Area of Rivers State, Nigeria. International Journal for Scientific and Engineering Research (Ijser), 8.

[2] Raimi, M. and Ezekwe, C. (2017) Assessment of Trace Elements in Surface and Ground Water Quality. LAP Lambert Academic Publishing, Mauritius.

[3] Raimi, M.O., Pigha, T.K. and Ochayi, E.O. (2017) Water-Related Problems and Health Conditions in the Oil Producing Communities in Central Senatorial District of Bayelsa State. Imperial Journal of Interdisciplinary Research (IJIR), 3.

[4] Erickson, J.J., Smith, C.D., Goodridge, A. and Nelson, K.L. (2017) Water Quality Effects of Intermittent Water Supply in Arraiján, Panama. Water Research, 114, 338-350. https://doi.org/10.1016/j.watres.2017.02.009

[5] Bikundia, D.S. and Mohan, D. (2014) Major Ion Chemistry of the Ground Water at 
the Khoda Village, Ghaziabad, India. Sustainability of Water Quality and Ecology, 3, 133-150. https://doi.org/10.1016/j.swaqe.2014.12.001

[6] Zlatanović, L., Van Der Hoek, J.P. and Vreeburg, J.H.G. (2017) An Experimental Study on the Influence of Water Stagnation and Temperature Change on Water Quality in a Full-Scale Domestic Drinking Water System. Water Research, 123, 761-772. https://doi.org/10.1016/j.watres.2017.07.019

[7] Heibati, M., Stedmon, C.A., Stenroth, K., Rauch, S., Toljander, J., Säve-Söderbergh, M. and Murphy, K.R. (2017) Assessment of Drinking Water Quality at the Tap Using Fluorescence Spectroscopy. Water Research, 125, 1-10. https://doi.org/10.1016/j.watres.2017.08.020

[8] Jassas, H. and Merkel, B. (2015) Assessment of Hydrochemical Evolution of Groundwater and Its Suitability for Drinking and Irrigation Purposes in Al-Khazir Gomal Basin, Northern Iraq. Environmental Earth Sciences, 74, 6647-6663. https://doi.org/10.1007/s12665-015-4664-4

[9] Edet, A. (2016) Hydrogeology and Groundwater Evaluation of a Shallow Coastal Aquifer, Southern Akwa Ibom State (Nigeria). Applied Water Science, 7, 2397-2412. https://doi.org/10.1007/s13201-016-0432-1

[10] Dhamodharan, A., Shanthakumar, S. and Ganapathy, G.P. (2016) Assessment of Seasonal Disparity on Hydrogeochemical Facies Distribution in Cooum River, India. Asian Journal of Earth Sciences, 9, 27-31. https://doi.org/10.3923/ajes.2016.27.35

[11] Li, P., Wu, J. and Qian, H. (2016) Hydrochemical Appraisal of Groundwater Quality for Drinking and Irrigation Purposes and the Major Influencing Factors: A Case Study in and around Hua County, China. Arabian Journal of Geosciences, 9, 15. https://doi.org/10.1007/s12517-015-2059-1

[12] Nagaraju, A., Muralidhar, P. and Sreedhar, Y. (2016) Hydrogeochemistry and Groundwater Quality Assessment of Rapur Area, Andhra Pradesh, South India. Journal of Geoscience and Environment Protection, 4, 88-99. https://doi.org/10.4236/gep.2016.44012

[13] Kumar, S.K., Babu, S.H., Rao, P.E., Selvakumar, S., Thivya, C., Muralidharan, S. and Jeyabal, G. (2017) Evaluation of Water Quality and Hydrogeochemistry of Surface and Groundwater, Tiruvallur District, Tamil Nadu, India. Applied Water Science, 7, 2533-2544. https://doi.org/10.1007/s13201-016-0447-7

[14] Tiwari, A.K., Singh, A.K., Singh, A.K. and Singh, M.P. (2017) Hydrogeochemical Analysis and Evaluation of Surface Water Quality of Pratapgarh District, Uttar Pradesh, India. Applied Water Science, 7, 1609-1623. https://doi.org/10.1007/s13201-015-0313-Z

[15] Efe, S.I. (2010) Spatial Variation in Acid and Some Heavy Metal Composition of Rainwater Harvesting in the Oil Producing Region of Nigeria. Natural Hazard, 55, 307-319.

[16] Ayoade, J.O. (2003) Tropical Hydrology and Water Resources. Agbo Areo Publishers, Ibadan, 206-209.

[17] Ovrawah, L. and Hymore, F.K. (2001) Quality of Water from Hand-Dug Wells in the Warri Environs of Niger Delta Region. African Journal of Environmental Studies, 2, 16-17.

[18] APHA (1998) Standard Methods for the Examination of Waste Water. 20th Edition, APHA Inc., New York, 2-134.

[19] Dami, A., Ayuba, H.K. and Amukali, O. (2013) Groundwater Pollution in Okpai and Beneku, Ndokwa-East Local Government Areas of Delta State, Nigeria. Journal 
of Environmental Research and Management, 4, 171-179.

[20] Chapman, D. and Kimstach, V. (1992) Selection of Water Quality Variables. In: Chapman, D., Ed., Water Quality Assessments, Chapman and Hall, London, 51-119. https://doi.org/10.4324/9780203476710

[21] Chukwu, O. (2008) Analysis of Groundwater Pollution from Abattoir Waste in Minna. Nigeria. Research Journal of Diary Science, 2, 74-77.

[22] Dami, A., Ayuba, H.K. and Amukali, O. (2012) Effects of Gas Flaring and Oil Spillage on Rainwater Collected for Drinking in Okpai and Beneku, Delta State, Nigeria. Global Journal of Human Social Sciences, 12, 7-10.

[23] Ejelonu, B.C., Adeleke, B.B., Ololade, I.O. and Adegbuyi, O. (2011) The Chemistry of Rainwater Sample Collected within Utorogu-Oil Producing Community in Niger Delta, Nigeria II. European Journal of Scientific Research, 58, 216-250.

[24] Murdoch, T., Cheo, M. and O'Laughlin, O. (2001) Streamkeeper's Field Guide: Watershed Inventory and Stream Monitoring Methods. Adopt-A-Stream Foundation, Everett, 297.

[25] Rosborg, I. (2002) Inorganic Constituents of Well Water in One Acid and One Alkaline Area of South Sweden. Water, Air, \& Soil Pollution, 142, 142-277.

[26] Opuene, K. and Agbozu, I.E. (2008) Relationships between Heavy Metal in Shrimp (Macro brachium felicinum) and Metal Levels in the Water Column and Sediments of Taylor Creek. International Journal of Environmental Research, 2, 343-348.

[27] Abowei, J.F.N. (2010) Salinity, Dissolved Oxygen, $\mathrm{pH}$ and Surface Water Temperature Conditions in Nkoro River, Niger Delta, Nigeria. Advance Journal Food Science Technology, 2, 16-21.

[28] Beadle, L.C. (1981) The Inland Waters of Tropical Africa. An Introduction to Tropical Limnology. Longman Publishers, London, 475.

[29] Aguwamba, J.C. (2000) Water Engineering Systems. Immaculate Publication Limited, Ogui N/Layout, Enugu.

[30] World Health Organisation (1993) Guidelines for Drinking Water Quality. 3rd Edition, Geneva, 41-62.

[31] World Health Organisation (2008) Guidelines for Drinking Water Quality. http://www.who.int/water_sanitation_health/dwq/guidelines/en/

[32] Udoessien, E.I. (2003) Basic Principles of Environmental Science. Etiliew International Publishers, Uyo, 77-110.

[33] Longe, E.O. and Enekwechi, L.O. (2007) Investigation on Potential Groundwater Impacts and Influence of Local Hydrogeology on Nature Attenuation of Leachate at Municipal Landfill. International Journal of Environmental Science and Technology, 4, 133-140. https://doi.org/10.1007/BF03325971

[34] Ushie, F.A. and Amadi, P.A. (2008) Chemical Characteristics of Groundwater from Parts of the Basement Complex of Oban Massif and Obudu Plateau, South Eastern Nigeria. Sciences Africa, 7, 81-88.

[35] Emoyan, O.O., Ogban, F.E. and Akarah, E. (2009) Evaluation of Heavy Metals Loading of River Ijana, Nigeria. Journal of Applied Sciences on Environmental Management, 10, 121-127. https://doi.org/10.4314/jasem.v10i2.43690

[36] Akporido, S.O. (2000) Analysis of Quality Characteristics of Surface and Groundwater. Nigeria Journal of Science and Environment, 2, 17-22.

[37] Ahmed, A.A., Green, A.V. and Seddiique, M. (2003) Community Wells to Mitigate the Arsenic Crisis in Bangladesh. Bulletin of the World Health Organisation, 81, 632-658. 
[38] Egila, J.N., Iroegbu, T.C. and Salami, S.J. (2001) Impact of Refuse Dump Sites on Ground Water Quality in Jos, Bukuru and Environment, Nigeria. Global Journal of Pure and Applied Sciences, 3, 437-441.

[39] Edet, A.E. and Ntekim, E.U. (1996) Heavy Metal Distribution in Ground Waterfrom Akwa Ibom State, Eastern Niger Delta, Nigeria-A Preliminary Pollution Assessment. Global Journal of Pure and Applied Sciences, 2, 67-71.

[40] Moriber, G. (1994) Environmental Sciences. Allyne and Bacon Inc., Boston, 211-261.

[41] Udo, E.E. (2004) Comparative Studies on the Concentration of Some Heavy Metals in Fish, Water, Sediment Samples from Ikot Abasi River in Ikot Abasi L.G.A of Akwa Ibom State. Unpublished M.Sc. Thesis, University of Uyo, Uyo, 84-98.

[42] Udosen, E.D. (2015) Variations in the Oxygen and Some Related Pollution Parameters in Some Streams in Itu Area of Nigeria. Journal of Environmental Sciences, 12, 75-80.

[43] Waziri, M. (2006) Physicochemical and Bacteriological Investigation of Surface and Ground Water of the Kumadugu-Yobe Basin of Nigeria. Unpublished PhD Thesis, Department of Chemistry, University of Maiduguri, Maiduguri, 24-186.

[44] Folkl, A. (2011) Iron Levels in Drinking Water. http://www.livestrong.com/article/91411-iron

[45] United States Geological Survey (USGS) (2002). http://ga.water.usgs.gov/edu/waterquality

[46] Groopman, J.D., Wolff, T. and Distlerath, L.M. (1985) Substrate Specificity of Human Liver Cytochrome p-450 Debrisoquine 4-Hydroxylase Probed Using Immunochemical Inhibition and Chemical Modeling. Cancer Research, 45, 2116-2122.

[47] Eja, M.E. (2002) Water Pollution and Sanitation for Developing Countries. Seas Print (Nig) Company, Calaber, 5-9.

[48] Emoyan, O.O., Ogban, F.E. and Akarah, E. (2006) Evaluation of Heavy Metals Loading of River Ijana in Ekpan-Warri, Nigeria. Journal of Applied Sciences on Environmental Management, 10, 121-127. 